\title{
AUSONIUS ON THE CENTO TECHNIQUE (CENTO, PRAEF. 26-27)
}

\section{Olga V.Budaragina}

Saint Petersburg State University, 7-9, Universitetskaya nab., St. Petersburg, 199034, Russian Federation; o.budaragina@spbu.ru

Bibliotheca classica Petropolitana, 9/6, Malyi pr. P.S., St. Petersburg, 197198, Russian Federation; o.budaragina@spbu.ru

The article discusses a passage from the "Cento nuptialis" by Ausonius where he comments upon cento technique and specifies the maximum length of a continuous quotation from the original text of Vergil. The meaning of the MSS reading et sequens cum medio is not very sound, and the author considers three proposed additions and alterations: Th. Mommsen's et sequens <medius > cum medio (1883); L.Villani's et sequens. Cum medio (1898); and R. Green's unus <et unus> sequenti cum medio (1991). For better examination of these corrections, it seemed important to look at Ausonius' own poetical practice in the "Cento nuptialis" and to compare it with two longest preserved Latin Vergilian centos: the tragedy "Medea" by Hosidius Geta (end of the $2^{\text {nd }}$ century) and the "Cento Vergilianus de laudibus Christi" by Faltonia Proba (mid- $4^{\text {th }}$ century). In spite of some differences, all three centones show a similar tendency in the employment of the most frequent arrangements: two independent half-lines, ${ }^{1}$ independent hexametrical lines or one half-line accompanied by the following half-line in the next verse. The author believes that this can clarify the meaning of unus in Ausonius' passage in question. Refs 18. Proba.

Keywords: D. Magnus Ausonius, Cento nuptialis, cento technique, Vergil, Hosidius Geta, Faltonia

Ausonius wrote the "Cento nuptialis" in 368 in response to a request by emperor Valentinian, who had created a work in a similar genre and had invited the poet into competition. The latter did not have much choice and composed his 131 line Vergilian epithalamium dedicated to a fictious marriage incredibly quickly — during one day and night. The text has a prosaic preface addressed to Ausonius' friend the rhetorician Paulus Maximus and inter alia discusses how to write a hexametric cento. This is the only explicit instruction for a centonist preserved since the time of antiquity and that is why it is of peculiar interest to us.

Ausonius' advice concerns the use of caesurae and the length of continuous quotations from the original text. The latter point will be discussed in my paper.

Here is the passage in question:

Et si pateris, ut doceam docendus ipse, cento quid sit absolvam. Variis de locis sensibusque quaedam carminis structura solidatur, in unum versum ut coeant aut caesi duo aut unus et sequens <medius > cum medio, nam duos iunctim locare ineptum est et tres una serie merae nugae (Prete 1978).

The "Cento nuptialis" is transmitted in the so-called Z manuscript family that dates from the fifteenth century. While the verse parts should be obviously sound, the "technicalities of the prose passages have caused serious corruption". ${ }^{2}$ Let us first look at the

1 The term "half-line" is employed here, of course, tentatively because two Vergilian pieces join to make a new hexametric line according to various caesurae.

2 Green 1991, 519.

(C) St. Petersburg State University, 2017 
variant readings in the text. Though most manuscripts adopt sequens cited above, there are some notable divergences:

sexque (Laurentianus LI, 13); sesque (Mus. Brit. Regius 31); saepe (Guelpherbitanus 10, 9; Guelpherbitanus Gud. 145).

Almost all editors have chosen sequens except for Kathryn Thomas who - without arguments - has decided in favor of the adverb sesque (the same as sesqui — "one and a half times"). ${ }^{3}$

Before going further, it is necessary to comment on the adjective medius in the context. Here it seems to have not the usual meaning 'central' but rather 'half' (cf. Greek

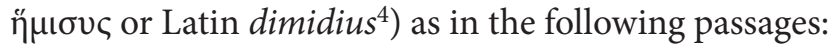

Tamquam frater mihi sis, medium abdomen tecum dividam (Pomp. Verres salvos 17980 Ribbeck).

Sufficiet magno arbori vehes una, minori media (Pallad. RR 3. 20. 2).

What is also important, is that Ausonius himself uses medius in the same sense. In his "Ratio dierum anni vertentis" he argues about the length of seasons and defines the duration of summer as ninety-four and a half days: ${ }^{5}$

Nonaginta dies et quattuor et medium Sol / conficit (Aus. Ecl. 15. 1 Prete = 8. 1 Green)

Most of the editors and commentators of the "Cento nuptialis" have approved 6 of Th. Mommsen's addition of medius after sequens, which was first published in the "Monumenta Germaniae Historica" by K. Schenkl in 1883. Mommsen's authority was so incontestable that some even incorporated the word into the text without brackets. ${ }^{7}$ According to this reading, the sense would be "a whole line and the following half-line" (so the maximum recommended length of Vergilian quotation would be one and a half lines).

L. Villani was the only one who defended the MSS reading and protested against Mommsen's conjecture during his lifetime. ${ }^{9}$ The scholar proposed to change the punctuation in the passage of Ausonius and to start a new sentence with cum medio:

$\langle\ldots\rangle$ in unum versum ut coeant aut caesi duo aut unus et sequens. Cum medio nam duos iunctim locare ineptum est $\langle\ldots\rangle$

As we have seen, the longest sequence of Vergilian text, according to Mommsen, could be one and a half lines. At the same time, Villani rightly noticed that sometimes the poet exceeds this. ${ }^{10}$ Villani took Ausonius' "rule" very seriously and did not want to assume that it was possible to deviate from it. If one accepts Villani's new punctuation, Ausonius recommends using two half-lines or two whole lines - unus et sequens (ironically, the

3 Thomas 1974, 193.

4 TLL s. v. II, A, 1, a.

5 According to Plinius the Elder, summer is two days shorter - ninety-two and a half days ( $\mathrm{NH} \mathrm{18,}$ 220-223).

${ }^{6}$ Peiper (1886), Evelyn White (1919), Prete (1978, Bright (1994), Dräger (2011).

7 Jasinski (1935).

8 M. Gasparov wrongly translates unus et sequens <medius>cum medio as «два стиха не подряд» (Gasparov 1993, 122).

9 Villani 1898, 106-107.

10 Cento 75-76; 97-98. 
scholar did not notice that once Ausonius quotes two and a half verses ${ }^{11}$ ). Soon after the publication, this suggestion was convincingly criticized by R. Helm on stylistic grounds ${ }^{12}$ who pointed to an unusual emphasis on cum medio and to a postpositive use of nam. ${ }^{13}$

Another person who - much later - refused to accept Mommsen's addition was R. Green. ${ }^{14}$ His tentative reconstruction of Ausonius' text is the following:

$<\ldots>$ aut unus $\leq$ et unus $>$ sequenti cum medio $<\ldots>$

"one half-line and one accompanied by the following half-line" (transl. by Green)

As one can see, Green understands unus as a "half-line" (unus <caesus versus $>$ ). His correction has been accepted in some recent publications on cento. ${ }^{15}$ What I find attractive in this reconstruction is the fact that it better suits Ausonius' poetical practice, as I will try to show below. ${ }^{16}$ At the same time, an example of an extremely rare combination of unus et unus cited by Green in corroboration of his argument is not convincing enough. In a facetious letter to his friend Theon, Ausonius thanks him for the gift of thirty oysters and plays with various ways to calculate this number, such as:

Septenis quater adde unum et unum ${ }^{17}(E p .13 .27$ Prete $=E p .14$ b 27 Green $)$

"To four times seven add one and one."

For some reason, Ausonius has chosen a very mannerist way to say "thirty": $7 \times 4+1+1$, but the context is purely arithmetical and has nothing to do with literary issues. Another reason against Green's version would be a rather inelegant triple usage of unus in the same sentence.

For better consideration of Mommsen's and Green's corrections, it seems important to look at Ausonius' own poetical practice in the "Cento nuptialis" and to compare it with the two longest preserved Latin Vergilian centones: the tragedy "Medea" by Hosidius Geta written presumably at the end of the $2^{\text {nd }}$ century and the "Cento Vergilianus de laudibus Christi" by the earliest extant female Christian poet Faltonia Proba who wrote it in the mid- $4^{\text {th }}$ century.

I would like to stress again that I have in mind continuous quotations from the original.

Here are some examples for all arrangements found in Ausonius:

As Table 1 shows, cento technique was by no means a Procrustean bed, and all three authors have their own predilections in making their "patch-work". At the same time, and this seems quite significant to me - one can observe a similar tendency in the employment of the most frequent arrangements (marked in bold in the Table). They obviously prefer to use two independent half-lines. The second place belongs to independent hexametrical lines. The third frequent arrangement found in centos is one half-line accompanied by the following half-line in the next verse.

\footnotetext{
11 Cento 24-26.

12 Helm 1899, 1577.

13 His arguments are repeated by Green $(1991,520)$.

14 Ibid.

15 McGill 2005, 2-3; Okáčová 2009, n. 53; Ehrling 2011, 15.

16 There are eleven examples of this arrangement in the "Cento nuptialis".

17 Green has unam et unam.
} 


\begin{tabular}{|l|c|c|c|c|c|c|}
\hline \multirow{2}{*}{} & \multicolumn{2}{|c|}{$\begin{array}{c}\text { "Cento nuptialis" } \\
(131 \text { hexameters) }\end{array}$} & \multicolumn{2}{c|}{$\begin{array}{c}\text { "Medea" } \\
(341 \text { hexameters })^{18}\end{array}$} & \multicolumn{2}{c|}{$\begin{array}{c}\text { "Cento Vergilianus } \\
\text { de laudibus Christi" } \\
(670 \text { hexameters) }\end{array}$} \\
\cline { 2 - 7 } & No & $\%$ & No & $\%$ & No & $\%$ \\
\hline $1 / 2+1 / 2$ (in one line) & $\mathbf{8 3}$ & $\mathbf{6 3 , 4}$ & $\mathbf{2 0 4}$ & $\mathbf{5 9 , 8}$ & $\mathbf{3 5 9}$ & $\mathbf{5 3 , 6}$ \\
\hline whole lines & $\mathbf{2 8}$ & $\mathbf{2 1 , 4}$ & $\mathbf{9 4}$ & $\mathbf{2 7 , 8}$ & $\mathbf{2 0 4}$ & $\mathbf{3 0 , 5}$ \\
\hline $1 / 2+1 / 2$ (in two following lines) & $\mathbf{1 1}$ & $\mathbf{8 , 4}$ & $\mathbf{2 7}$ & $\mathbf{7 , 9}$ & $\mathbf{2 7}$ & $\mathbf{4}$ \\
\hline $1 / 2+$ whole line & 7 & 5,3 & - & - & 14 & 2,1 \\
\hline whole line $+1 / 2$ & 5 & 3,8 & 2 & 0,6 & 26 & 3,9 \\
\hline $1 / 2+$ whole line $+1 / 2$ & - & - & - & - & 4 & 0,6 \\
\hline two and more lines & 3 & 2,3 & - & - & 3 & 0,5 \\
\hline $1 / 3+1 / 3+1 / 3$ & - & - & 4 & 1,2 & 15 & 2,2 \\
\hline versus imperfecti & - & - & 7 & 2 & 2 & 0,3 \\
\hline
\end{tabular}

Table 2

\begin{tabular}{|c|c|c|c|}
\hline $1 / 2+1 / 2($ in one line $)$ & Ambo florentes, | genus insuperabile bello; & Cento 3 & $\begin{array}{l}\text { Ecl. 7. 4; Aen. } \\
\text { 4. } 40\end{array}$ \\
\hline whole line & Accipite haec animis laetasque advertite mentes & Cento 1 & Aen. 5. 304 \\
\hline $\begin{array}{l}1 / 2+1 / 2 \\
\text { (in two following } \\
\text { lines) }\end{array}$ & $\begin{array}{l}\text { Tuque prior, | nam te maioribus ire per altum } \\
\text { auspiciis manifesta fides, | quo iustior alter }\end{array}$ & $\begin{array}{l}\text { Cento } \\
4-5\end{array}$ & $\begin{array}{l}\text { Aen. } 6.834 ; \\
\text { Aen. } 3.374 \\
\text { Aen. } 3.375\end{array}$ \\
\hline $1 / 2+$ whole line & $\begin{array}{l}\text { Virginis os habitumque gerens, | cui plurimus ignem } \\
\text { subiecit rubor et calefacta per ora cucurrit }\end{array}$ & Cento 35-36 & $\begin{array}{l}\text { Aen. } 1.315 ; \\
\text { Aen. } 12.65 \\
\text { Aen. } 12.66\end{array}$ \\
\hline whole line $+1 / 2$ & $\begin{array}{l}\text { Conveniunt stratoque super discumbitur ostro. } \\
\text { Dant famuli manibus | lymphas onerantque canistris }\end{array}$ & Cento $14-15$ & $\begin{array}{l}\text { Aen. } 1.700 \\
\text { Aen. } 1.701 \\
\text { Aen. } 8.180 \\
\end{array}$ \\
\hline two and more lines & $\begin{array}{l}\text { Sacra canunt, | plaudunt choreas et carmina dicunt. } \\
\text { Nec non Thraeicius longa cum veste sacerdos } \\
\text { obloquitur numeris septem discrimina vocum. }\end{array}$ & $\begin{array}{l}\text { Cento } \\
24-26\end{array}$ & $\begin{array}{l}\text { Aen. 2. 239; } \\
\text { Aen. 6, 644 } \\
\text { Aen. 6, } 645 \\
\text { Aen. 6,646 }\end{array}$ \\
\hline
\end{tabular}

Now let us come back to the passage of Ausonius in question. One would assume that the poet is expected to give recommendations according to his own practice and the common practice of other centonists. Ausonius starts with two half-lines which are - as we have seen - the prevalent way to make a cento hexameter. Mommsen's addition of medius makes sense, but the arrangement "a whole line with the following half-line" is only the fifth most frequent in Ausonius. Green's daring conjecture aut unus <et unus> sequenti cum medio ("one half-line and one accompanied by the following half-line") takes only the third place in the "Cento nuptialis", as well as in Hosidius Geta and Faltonia Proba. It also seems rather inappropriate that Ausonius should discuss only two possibilities for a centonist: two independent half-lines and a whole line with the following half-line

\footnotetext{
${ }_{18}$ Excluding the choral passages, which consist of paroemiacs. Total number of lines is 437.

19 Excluding lines 1-23 which are written entirely or partly by Faltonia Proba. Line 234 is missing in the manuscripts. Total number of lines is 694 .
} 
(Mommsen) or one half-line and one accompanied by the following half-line (Green). I assume that the author of "Cento nuptialis" somehow mentions here all three most frequent arrangements.

To sum up, Ausonius explicitly does not approve of using in a cento two and more lines from the original text. This leaves us with a maximum length of one and a half lines. The problem is that this sense cannot be detected from the passage in question. Thus, I believe that it's last part is very likely to be seriously corrupted ${ }^{20}$ and propose to put a crux desperationis after unus:

$<\ldots>$ unus $\dagger \mathrm{et}^{21}$ sequens cum medio $<\ldots>$

At the same time, unus itself is very likely to be sound and it should mean not a 'half-line' (unus <caesus $>$ ) but a 'whole line' (unus <versus $>$ ). Ausonius, I think, prescribes here (according to his own and common practice) the second most frequent arrangement used - an independent hexametrical line.

\section{References}

Bright D. Theory and Practice in the Vergilian Cento. Illinois Classical Studies 1984, 9/1, 79-90.

Dräger P. (Hg., Übers.) Decimus Magnus Ausonius. Sämtliche Werke II. Trier, Kliomedia, 2011.

Ehrling S. De inconnexis continuum: A Study of Late Antique Latin Wedding Centos. Göteborg, Göteborgs Universitet, 2011.

Evelyn White H. (ed., transl.) Ausonius. London - Cambridge, MA, Harvard University Press, 1919 (=1951).

Fassina A., Lucarini C. (ed.) Faltonia Betitia Proba. Cento Vergilianus. Berlin, de Gruyter, 2015.

Gasparov M. L. (transl.) Avsonii [Ausonius], Moscow, Nauka, 1993 (in Russian).

Green R. (ed.) The Works of Ausonius. Oxford, Clarendon Press, 1991.

Helm R. Ausonius. Berliner philologische Wochenschrift 1899, 19, 1576-1577.

Jasinski M. (ed., trad.). Ausone. Oeuvres en vers et en prose. Paris, Classiques Garnier, 1934.

McGill S. Virgil Recomposed: The Mythological and Secular Centos in Antiquity. Oxford, OUP, 2005.

Okáčová M. Centones: Recycled Art or the Embodiment of Absolute Intertextuality? 2009. http://www.kakanien.ac.at/beitr/graeca_latina/MOkacova1.pdf (04.04.2017).

Peiper R. (ed.) Decimi Magni Ausonii Burdigalensis opuscula. Leipzig, Teubner, 1886.

Prete S. (ed.) Ausonius Opuscula. Leipzig, Teubner, 1978.

Reeve M. The Tilianus of Ausonius. Rheinisches Museum für Philologie, 1978, 121, 3-4, 350-366.

Rondholz A. The Versatile Needle. Hosidius Geta's Cento Medea and its Tradition. Berlin - Boston, De Gruyter, 2012.

Schenkl C. (ed.) D. Magni Ausonii opuscula. MGH V. Berolini, Weidmann, 1883.

Thomas K. A Critical Text of the Praefatiunculae, Cento Nuptialis, and Selections from the Appendix to the Works of Decimus Magnus Ausonius. Diss. Chicago, Loyola University, 1974.

Villani L. Per la critica di Ausonio. Studi italiani di filologia classica 1898, 6, 97-119.

For citation: Olga V. Budaragina. Ausonius on the Cento Technique (Cento, Praef. 26-27). Philologia Classica 2017, 12(1), 48-53. DOI: 10.21638/11701/spbu20.2017.106.

\section{АВЗОНИЙ О ТЕХНИКЕ СОСТАВЛЕНИЯ ЦЕНТОНОВ (CENTO, PRAЕF. 26-27)}

\section{Ольга Владимировна Бударагина}

Bibliotheca classica Petropolitana, 197198, Российская Федерация,

Малый проспект П.С., 9/6; o.budaragina@spbu.ru

Санкт-Петербургский государственный университет, Российская Федерация, 199034, Санкт-Петербург, Университетская наб., 7-9; o.budaragina@spbu.ru

20 Some "corruption at an earlier state" was supposed by M. Reeve (1978, 361-2).

${ }^{21}$ Could it be a corruption of aut? 
В статье анализируется свидетельство Авзония - единственное дошедшее от времен античности детализированное указание на практику составления гекзаметрических центонов, а именно то место, где поэт оговаривает максимально возможное количество стихов оригинала, которое допустимо подряд использовать в центоне. Поскольку чтение большинства рукописей et sequens cum medio вызывает трудности, рассматриваются предложенные раньше дополнения и конъектуры: et sequens <medius> cum medio T. Моммзена (1883); et sequens. Cum medio Л. Виллани (1898) и ипиs <et unus > sequenti cum medio Р. Грина (1991). Для того чтобы лучше оценить предложенные исправления, автор привлекает статистическое исследование стихотворной практики самого Авзония и сопоставляет ее с двумя самыми длинными латинскими вергилиевскими центонами - трагедией «Медея» Госидия Геты (конец II в.) и «Cento Vergilianus de laudibus Christi» Фальтонии Пробы (середина IV в.). Несмотря на различия в деталях, все три центона едины в выборе наиболее частых способов цитирования текста Вергилия: две несвязанных «половинки» гекзаметра, целый стих или две связанных «половинки» в соседних стихах. Как кажется, эти наблюдения могут уточнить значение unus в разбираемом пассаже Авзония. Библиогр. 18 назв.

Ключевые слова: Д. Магн Авзоний, «Cento nuptialis», техника центонов, Вергилий, Госидий Гета, Фальтония Проба.

Received 16.03.2017

Final version received 03.05.2017 